\title{
Theory of Planned Behavior Application to ANC behavior for Early Detection of Pregnancy Risk in Public Health Center Saronggi, Sumenep Regency
}

\author{
Siti Zainurrah ${ }^{1}$, Katmini $^{2}$ \\ ${ }^{1}$ Health Center Saronggi Sumenep \\ ${ }^{2}$ Strada Indonesian Institute of \\ Health Sciences \\ Email: \\ sitizinurrah@gmail.com
}

Received : October $4^{\text {nd }} 2021$

Accepted : October $15^{\text {rd }} 2021$

Published : November $27^{\text {th }} 2021$

\begin{abstract}
Antenatal care services are basic health services for pregnant women that must be carried out according to standards, namely at least 4 times during pregnancy. Each pregnancy can develop into problems or complications, so monitoring is necessary during pregnancy. The purpose of this study was to analyze the effect of attitudes and norms on ANC behavior for early detection of pregnancy risk at the Saronggi Health Center, Sumenep Regency. The design of this study is a quantitative observational study with a cross sectional approach with the focus of the research being directed at analyzing the influence of attitudes and norms on ANC behavior for early detection of pregnancy risk at the Saronggi Health Center, Sumenep Regency. The total population is 134 respondents and a sample of 100 respondents is taken using the Simple Random Sampling technique. Data analysis using Linear Regression test. The results showed thatalmost half of the respondents have attitudes in the moderate category, 46 respondents $(46 \%)$. Most of the respondents have a norm in the sufficient category of 52 respondents (52\%). Almost half of the respondents have behavior in the moderate category, as many as 48 respondents (48\%).Based on the results of Multiple Linear Regression analysis shows that with a p-value of $0.000<0.05$ then $\mathrm{H} 1$ is accepted so it can be concluded that simultaneously there is the influence of attitudes and norms on ANC behavior for early detection of pregnancy risk at the Saronggi Health Center, Sumenep Regency with a magnitude of $86.9 \%$. It is expected that respondents can carry out Integrated ANC regularly and follow all the treatment agendas that must be carried out during pregnancy in order to avoid the risk of pregnancy.
\end{abstract}

Keywords: Integrated ANC, norms, behavior \& attitude

Copyright C 2021 IIK STRADA Indonesia All right reserved.

This is an open-acces article distributed under the terms of the Creative Commons AttributionShareAlike 4.0 International License.

\section{INTRODUCTION}

Antenatal care services are basic health services for pregnant women that must be carried out according to standards, namely at least 4 times during pregnancy. Each pregnancy can develop into problems or complications, so monitoring is necessary during pregnancy. Pregnant women should also know about the dangers of pregnancy. If pregnant women know about the dangers of pregnancy, then 
pregnant women will be more alert and careful by routinely carrying out examinations during their pregnancy. The worst possibility is that pregnancy complications can cause death in pregnant women (Suwargono, 2015).

Maternal Mortality Rate should be prevented by early detection of high risk or complications during pregnancy, by conducting visits or antenatal care to available health services. The presence of high maternal mortality indicates the low quality of maternal health services, including antenatal care (ANC) services for pregnant women (Suwargono, 2015).

If the quality of antenatal care services is not good, it will affect the initial visit of pregnant women (K-1) and the second visit in the third trimester (K-4) which will affect the maternal mortality rate and infant mortality rate. This is evident from the data obtained from the Sumenep District Health Office in 2013 the percentage of the initial visit for pregnant women (K-1) was $99 \%$ and the second visit in the third trimester (K-4) $90 \%$ still did not meet the 2015 national target, namely the target for (K-1) $100 \%$ and the target for (K-4) $100 \%$. The Maternal Mortality Rate (MMR) is still there at 157.39/100,000 live births and the Infant Mortality Rate (IMR) is still there at 10.59/1000 live births. Delivery by health workers (nakes delivery) $91 \%$ also still does not meet the target of $95 \%$ (Sumenep Health Office, 2014).

Based on reports that the maternal mortality rate (MMR/MMR) in the last 10 years in Indonesia has fluctuated from 307 per 100,000 live births in 2002 or $0.08 \%$ down to 228 per 100,000 live births in 2012 or $0.26 \%$ and then increased drastically to 359 per 100,000 live births or $0.57 \%$ in 2012 . Has a MMR target in the MDG'S 2020. (WHO 2020).

Various national MCH policies have been issued by the government, such as the Making Pregnancy Safer (MPS) strategy in response to the WHO which launched the Safe Motherhood Initiative in 1987. For three decades, 1980-2010, Indonesia was a successful country in managing the $\mathrm{MCH}$ program, however, on the contrary, MMR fluctuations occurred, which meant that the achievement of MMR targets had declined from year to year. Several other related programs to support efforts to increase MCH are DTPS - KIBBLA (District Team Problem Solving Maternal Health). This program has six DTPS KIBLA approach programs, namely Kangaroo Treatment Method (PMK), Desa Sire, SBMR (Standard Based Management Recognition). And AMP ( Perinatal Maternity Care) . Delivery Planning and Complication Prevention ( P4K ) Program. Maternal Love Movement (GSI), Maternity Insurance (Jampersal) and Health Operational Assistance (BOK). It also has not been able to reduce MMR (WHO, 2015).

ANC or antenatal care is the care of the mother and fetus during pregnancy. Through anc, various information and education related to pregnancy and preparation for delivery can be given to mothers as early as possible. Lack of knowledge about the danger signs of pregnancy often occurs because the lack of these visits can cause danger to the mother and fetus such as bleeding during pregnancy because no danger signs are detected. (WHO, 2016).

WHO recommends several things related to ANC such as the importance of developing clinical policies and protocols related to maternal and child health. This guide is in accordance with standard operating procedures (SOP) which includes identification of prioritized problems and expected outcomes. Gathering evidence of reported issues, assessing existing ones, formulating recommendations and planning for implementation, dissemination, and impact and evaluation (WHO 2016).

The Ministry of Health of the Republic of Indonesia has compiled Guidelines for Integrated Antenatal Services. These guidelines are expected to be a reference for health workers in providing quality integrated Antenatal services to improve maternal health status which in turn will contribute to reducing maternal mortality. The Integrated ANC Guidelines were prepared by the Directorate General of Community Health based on input from the expert team and Evidence Based in the field which was then introduced in 2010 through the Directorate General of Public Health.

With the formulation of Antenatal Care service guidelines, it can be a benchmark for the success of ANC, which means it can save lives or reduce AKI. Through the ANC, the opportunity to deliver education and health promotion to pregnant women in particular can be done better (WHO, 2016). With this achievement, the satisfaction of pregnant women with health services in caring for their pregnancy will increase and there will be no worries about the incidence of maternal and fetal death, besides that, it can also reduce the possibility of the baby being born with defects.

Based on the above conditions, the authors are interested in researching the application of 
Theory of Planned Behavior to ANC behavior for early detection of pregnancy risk at the Saronggi Health Center, Sumenep Regency.

\section{MATERIALS AND METHODS}

In this study, the researcher used an observational quantitative design with a cross sectional approach, which is a study to study the dynamics of the correlation between risk factors and effects, by approaching, observing or collecting data all at once (point time approach), that is, each subject The study was observed only once and measurements were made on the status of the character or variable of the subject at the time of examination. This does not mean that all research subjects are observed at the same time (Soekidjo, 2012). This research will analyzethe influence of attitudes and norms on ANC behavior for early detection of pregnancy risk at the Saronggi Health Center, Sumenep Regency. The total population of 134 respondents and a sample of 100 respondents were taken using the Simple Random Sampling technique. Data analysis using Linear Regression test. This research has gone through a series of ethical testing processes with the number SK:2319/KEPK/III/2021.

\section{RESULTS}

Table 1 The results of the Linear Regression statistical test for the Theory of Planned Behavior application on ANC behavior for early detection of pregnancy risk at the Saronggi Health Center, Sumenep Regency conducted by researchers on 1-29 June 2021 with a total of 100 respondents

\begin{tabular}{|c|c|c|c|c|}
\hline No & Variable & Sig & $R^{2}$ & Sig \\
\hline 1 & constant & .000 & & \multirow{2}{*}{0.869} \\
\cline { 1 - 2 } 2 & Attitude & .004 & 0.000 \\
\hline 3 & Norm & .002 & & \\
\hline
\end{tabular}

\section{Partial}

a. Influence of Attitude on Behavior

Based on the results of Linear Regression analysis shows that the p-value is 0.004 $<0.05$ then $\mathrm{H} 1$ is accepted so it is concluded that partially there is the influence of attitudes on ANC behavior for early detection of pregnancy risk at the Saronggi Health Center, Sumenep Regency

b. The Influence of Norms on Behavior

Based on the results of Linear Regression analysis shows that the p-value is 0.002 $<0.05$, then $\mathrm{H} 0$ is rejected and $\mathrm{H} 1$ is accepted, so it can be concluded that partially there is the influence of norms on ANC behavior for early detection of pregnancy risk at the Saronggi Health Center, Sumenep Regency

\section{Simultaneous}

Based on the results of Multiple Linear Regression analysis shows that with a p-value of $0.000<0.05$ then $\mathrm{H} 1$ is accepted so it can be concluded that simultaneously there is the influence of attitudes and norms on ANC behavior for early detection of pregnancy risk at the Saronggi Health Center, Sumenep Regency with a magnitude of $86.9 \%$.

\section{DISCUSSION}

\section{A. Mother's Attitude for Early Detection of Pregnancy Risk at the Saronggi Health Center,} Sumenep Regency

The results showed that almost half of the respondents had attitudes in the moderate category, 46 respondents (46\%). In addition, 39 respondents (39\%) had attitudes in the less category. While a number of 25 respondents $(25 \%)$ have an attitude in the good category.

Attitude is a reaction or response of someone who is still closed to a stimulus or object. The manifestation of that attitude cannot be directly seen, but can only be interpreted beforehand from closed behavior. According to Randi in Imam (2011), attitude is a general evaluation made by humans against themselves or others for reactions or responses to stimuli (objects) that cause feelings accompanied by actions that are in accordance with the object.

Attitudes clearly show the connotation of a suitability of reactions to certain stimuli (Notoatmodjo, 2012). Attitude consists of various levels, namely Receiving (Receiving) Receiving 
is defined, that people (subjects) want and pay attention to the given stimulus (object). Responding Giving answers when asked, doing and completing the given task is an indication of attitude. Because with an attempt to answer a question or do a given task, regardless of whether the job is right or wrong, it means that people accept the idea. Appreciating (Valuing) Inviting others to work on or discuss with others on a problem an indication of the third level of attitude.

Daniel Katz in Rina (2013) divides the attitude function into 4 categories, namely the utilitarian function, through likes and dislikes instruments, positive attitudes or satisfaction and rejection which gives positive results or satisfaction. Defensive ego function, People tend to develop certain attitudes to protect their ego from psychological abrasion. Psychological abrasion can arise from a work-addicted environment. Value expensive function, Expressing the values espoused by the function allows it to clearly express its self-image and also its core values. Knowledge-organization function, Due to the limited capacity of the human brain to process information, people tend to rely on knowledge gained from experience and information from the environment.

According to researchers, pregnant women have various attitudes, ranging from very concerned about their pregnancy to those who care less about it. The decision to act pregnant women about their pregnancy can be caused by many things ranging from internal factors and external factors. From the results of the study, it was found that many pregnant women had attitudes in the sufficient category, but there were still many pregnant women who had attitudes in the less category. Where this is because pregnant women do not really feel complaints during pregnancy so it is felt that there is no need to monitor pregnancy by health workers, especially midwives.

B. Mother's Norms for Early Detection of Pregnancy Risks at the Saronggi Health Center, Sumenep Regency

The results showed that most of the respondents had the norm in the sufficient category as many as 52 respondents (52\%). In addition, a number of 27 respondents $(27 \%)$ have norms in the less category. Meanwhile, a number of 21 respondents (21\%) have norms in the good category.

Pregnancy is a state that every couple looks forward to. Pregnancy can bring joy to the mother. However, not all mothers experience joy over their pregnancy, pregnancy can provide a sense of anxiety for every mother. This is because some mothers experience pressure and worry about the pregnancy they are experiencing. This pressure increases in high-risk pregnant women (Astuti, 2013)

High-risk pregnancy is a pregnancy with conditions that can increase the risk of abnormalities or danger to the fetus. In high-risk pregnancies there are special measures for the mother and fetus. The health or even the life of the mother and fetus is in danger due to pregnancy disorders (Wijaya, 2015).

There are several risk factors in pregnancy which are indirect causes of maternal death, namely four too; too old, too young, too often and too much. In addition, there are conditions that cause pregnant women to be classified as high-risk pregnancies, namely; pregnant women with anemia and malnutrition, pregnant women with comorbidities, a bad history in previous pregnancies and deliveries, pregnant women with a height of less than $145 \mathrm{~cm}$, and unwanted pregnancies (Santoso, 2016)

According to researchers, pregnant women are aware of the importance of maternal and fetal health, but sometimes pregnant women also misunderstand something where pregnant women often limit eating because of tradition or pregnant women feel that the recommendations given by health workers are not good because they are not in accordance with the norms and traditions that apply in the environment. the. Based on the results of the study, it was found that most of the respondents had norms in the fairly good category, but there were still many respondents who had norms in the less category. Where this is because pregnant women do not trust the officers around their environment,

C. Maternal ANC Behavior for Early Detection of Pregnancy Risk at Saronggi Health Center, Sumenep Regency

The results showed that almost half of the respondents had behavior in the moderate category, as many as 48 respondents (48\%). In addition, a number of 38 respondents (38\%) have 
behavior in the less category. While a number of 24 respondents (24\%) have behavior in the good category.

Human behavior is the result of all kinds of experiences and human interactions with the environment that are manifested in the form of knowledge, attitudes and actions. In other words, behavior is a response / reaction of an individual to a stimulus that comes from outside or from within himself. This response can be passive (without action: think, think, behave) or active (take action). In accordance with this limitation, behavior can be formulated as a form of experience and interaction of individuals with their environment, especially those concerning knowledge and attitudes about themselves. Active behavior can be seen, while passive behavior is invisible, such as knowledge, perception, or motivation. Some experts distinguish forms of behavior into three domains, namely knowledge, attitudes,

From a biological point of view, behavior is an activity or activity of the organism concerned, which can be observed directly or indirectly. Human behavior is a human activity itself (Notoadmodjo, 2013).

American Encyclopedia, behavior is defined as an action-reaction of organisms to their environment. New behavior occurs when something is needed to cause a reaction, which is called a stimulus. It means that certain stimuli will produce certain reactions or behaviors (Notoadmodjo, 2013).

As quoted by Notoatmodjo (2013), behavior is an action or behavior of an organism that can be observed and even learned. In general, human behavior is essentially a process of individual interaction with the environment as a biological manifestation that he is a living being (Kusmiyati and Desminiarti, 2011). According to the author, what is called human behavior is an activity that arises because of a stimulus and response and can be observed directly or indirectly.

The process of forming or changing behavior can be influenced by several factors, both internal and external to the individual. Aspects within the individual that are very influential in changing behavior are perceptions, motivations and emotions. Perception is observation which is a combination of sight, hearing, smell and past experiences. Motivation is an impulse to act to satisfy a need. The impetus in motivation is manifested in the form of action (Sarwono, 2013).

According to Skinner (2016), a psychologist, formulates that behavior is a person's response or reaction to a stimulus (stimulus from outside). Human behavior in terms of biology is the action or activity of the human itself which has a very wide expanse such as walking, talking, crying, working and so on.

According to behavioral researchers is the result of all kinds of experiences and human interactions with the environment that are manifested in the form of knowledge, attitudes and actions. Behavior in pregnant women is generally very measured and very careful. Based on the results of the study, it was found that most of the respondents had behavior in the sufficient category, but many respondents had behavior in the less category where this was because pregnant women were too busy with their work as housewives or as entrepreneurs so that to carry out routine checks it was very burdensome. pregnant mother. In addition, because pregnant women do not trust what is recommended by health workers so that pregnant women prefer to do what their parents recommend.

D. The Influence of Attitudes on ANC Behavior for Early Detection of Pregnancy Risk at the Saronggi Health Center, Sumenep Regency

Based on the results of Linear Regression analysis shows that the p-value is $0.004<0.05$ then $\mathrm{H} 1$ is accepted so it is concluded that partially there is the influence of attitudes on ANC behavior for early detection of pregnancy risk at the Saronggi Health Center, Sumenep Regency.

ANC or antenatal care is the care of the mother and fetus during pregnancy. Through anc, various information and education related to pregnancy and preparation for delivery can be given to mothers as early as possible. Lack of knowledge about the danger signs of pregnancy often occurs because the lack of these visits can cause danger to the mother and fetus such as bleeding during pregnancy because no danger signs are detected. (WHO, 2016).

WHO recommends several things related to ANC such as the importance of developing clinical policies and protocols related to maternal and child health. This guide is in accordance with standard operating procedures (SOP) which includes identification of prioritized problems and expected outcomes. Gathering evidence of reported issues, assessing existing ones, 
formulating recommendations and planning for implementation, dissemination, and impact and evaluation (WHO 2016).

The Ministry of Health of the Republic of Indonesia has compiled Guidelines for Integrated Antenatal Services. These guidelines are expected to be a reference for health workers in providing quality integrated Antenatal services to improve maternal health status which in turn will contribute to reducing maternal mortality. The Integrated ANC Guidelines were prepared by the Directorate General of Community Health based on input from the expert team and Evidence Based in the field which was then introduced in 2010 through the Directorate General of Public Health.

According to researchers, the behavior of a pregnant woman is closely related to the attitude of a pregnant woman to something. Pregnant women who have attitudes in the good category tend to have behaviors in the good category to carry out Integrated ANC care, while pregnant women who have attitudes in the less category tend to have behaviors in the less category to carry out Integrated ANC care. So that according to the researcher's hypothesis, namely there is an effect of attitude on ANC behavior for early detection of pregnancy risk at the Saronggi Health Center, Sumenep Regency.

E. The Influence of Norms on ANC Behavior for Early Detection of Pregnancy Risk at Saronggi Health Center, Sumenep Regency

Based on the results of Linear Regression analysis shows that the p-value is $0.002<0.05$, then $\mathrm{H} 0$ is rejected and $\mathrm{H} 1$ is accepted, so it can be concluded that partially there is the influence of norms on ANC behavior for early detection of pregnancy risk at the Saronggi Health Center, Sumenep Regency.

Antenatal care services are basic health services for pregnant women that must be carried out according to standards, namely at least 4 times during pregnancy. Each pregnancy can develop into problems or complications, so monitoring is necessary during pregnancy. Pregnant women should also know about the dangers of pregnancy. If pregnant women know about the dangers of pregnancy, then pregnant women will be more alert and careful by routinely carrying out examinations during their pregnancy. The worst possibility is that pregnancy complications can cause death in pregnant women (Suwargono, 2015).

Maternal Mortality Rate should be prevented by early detection of high risk or complications during pregnancy, by conducting visits or antenatal care to available health services. The presence of high maternal mortality indicates the low quality of maternal health services, including antenatal care (ANC) services for pregnant women (Suwargono, 2015).

With the formulation of Antenatal Care service guidelines, it can be a benchmark for the success of ANC, which means it can save lives or reduce AKI. Through the ANC, the opportunity to deliver education and health promotion to pregnant women in particular can be done better (WHO, 2016). With this achievement, the satisfaction of pregnant women with health services in caring for their pregnancy will increase and there will be no worries about the incidence of maternal and fetal death, besides that, it can also reduce the possibility of the baby being born with defects.

According to researchers, the norms of pregnant women in the environment make pregnant women behave, because pregnant women in an environment that is still thick with cultural traditions tend to be more concerned with trust as a benchmark for all activities. Pregnant women who have norms in the good category tend to have behavior in conducting Integrated ANC in the good category, on the contrary, pregnant women who have norms in the less category also have behavior in conducting Integrated ANC in the less category. So it is in accordance with what the researcher wants, namely that there is an influence of norms on ANC behavior for early detection of pregnancy risk at the Saronggi Health Center, Sumenep Regency.

\section{CONCLUSION}

1. Almost half of the respondents have attitudes in the moderate category, 46 respondents $(46 \%)$.

2. SMost of the respondents have a norm in the sufficient category of 52 respondents (52\%).

3. Halmost half of the respondents have behavior in the moderate category as many as 48 respondents $(48 \%)$.

4. There is an effect of attitude on ANC behavior for early detection of pregnancy risk at the Saronggi Health Center, Sumenep Regency 
5. There is an influence of norms on ANC behavior for early detection of pregnancy risk at the Saronggi Health Center, Sumenep Regency

\section{SUGGESTION}

1. For Respondents

It is expected that respondents can carry out Integrated ANC regularly and follow all the treatment agendas that must be carried out during pregnancy in order to avoid the risk of pregnancy.

2. For Other Researchers

It is hoped that further research needs to be deepened and added more research on the effect of gestational age on high-risk events in pregnant women at the Saronggi Health Center, Sumenep Regency.

3. For Educational Institutions

It is hoped that educational institutions can use the results of this study as learning input in the influence of attitudes and norms on ANC behavior for early detection of pregnancy risk at the Saronggi Health Center, Sumenep Regency and can be developed again for further research to be more useful for readers and researchers.

\section{ACKNOWLEDGMENT}

I solemnly declare that to the best of my knowledge, in this thesis there is no scientific work that has been submitted by another person to obtain an academic degree at a university, and there is no work or opinion that has been written or ordered by anyone. others, except those quoted in this manuscript and mentioned in the citation sources and bibliography.

\section{CONFLICT OF INTEREST}

In this study, there is no interest whatsoever concerning myself or with other institutions other than the Indonesian Strada Institute of Health Sciences, Kediri City.

\section{REFERENCES}

Azizah N (2014) Pelaksanaan deteksi dini penyakit penyerta kehamilan pada pelayanan antenatal terkait kematian ibu di Kabupaten Kudus. JIKK. 2014;5(2): 9-21.

Budhihardja. (2010) Pedoman pelayanan antenatal terpadu. 2010 [diunduh 27 Maret 2015]. Tersedia dari: http://Pedoman-ANC-Terpadu.pdf

Coco L. (2014) Management of high-risk pregnancy. Minerva Ginecologica. 2014;66 (4):383-9.

Dinas Kesehatan Surabaya. (2014) Monitoring dan Evaluasi ANC Terpadu. Dinkes Surabaya 2014 [diunduh 23 Oktober 2020]. Tersedia dari: http://dinkes.surabaya.go.id

Erly M, Iyone ETS, Umboh JMI. (2013) Perilaku ibu hamil tentang antenatal care di Puskesmas Bahu Kecamatan Malalayang Kota Manado. 2013 [diunduh 23 Oktober 2020]. Tersedia dari: http:www.portalgaruda.org

Hamidi H. (2014) Pedoman-ANC-terpadu. 2014 April [diunduh 23 Oktober 2020]. Tersedia dari: http://pedoman-ANC-Terpadu.pdf

Kementerian Kesehatan RI. (2015) Profi kesehatan Indonesia 2012. Jakarta: Kementerian Kesehatan RI. 2013 [diunduh 23 Oktober 2020]. Tersedia dari : http://www. kemkes.go.id

Kementerian Kesehatan RI. (2015) Upaya menurunkan angka kematian ibu dan kematian bayi perlu kerja keras. Jakarta: Kementerian Kesehatan RI. 2010 [diunduh 23 Oktober 2020]. Tersedia dari: http://www. depkes.go.id

Mieke. (2013) Analisi implementasi program pelayanan antenatal terpadu pada ibu hamil dengan malaria di Puskesmas Tobelo Kabupaten Halmahera Utara Provinsi Maluku Utara. 2013 [diunduh 23 Oktober 2020]. Tersedia dari: http://www.eprints. undip.ac.id

Nissa AA, Surjani, Mardiyaningsih E. (2013) Gambaran kepuasan ibu hamil terhadap pelayanan antenatal care di Puskesmas Getasan Kebupaten Semarang. Jurnal Keperawatan Maternitas. 2013;1(1):21-7 
Prasetyo B, Had SN. (2013) Penerapan antenatal terpadu pada ibu hamil di wilayah kerja Puskesmas Sumobito Kabupaten Jombang. 2013 [diunduh 23 Oktober 2020]. Tersedia dari: http://www.penelitian.unair.ac.id

Saifudin AB. (2016) Buku panduan praktis pelayanan kesehatan maternal dan neonatal. Jakarta: Salemba Medika.

Senewel FP, Sulistiyowati N. (2014) Faktor-faktor yang berhubungan dengan komplikasi persalinan tiga tahun terakhir di Indonesia ( Analisis Lanjut SKRT-Suskernas 2001). Buletin Penelitian Kesehatan.;32( 2): 83-91.

Simarmata OS, Armagustini Y, Bisara D. (2010) Determinan Kejadian Komplikasi Persalinan di Indonesia Analisis Data Sekunder Riset Kesehatan Dasar. 2010 [diunduh 23 Oktober 2020]. Tersedia dari: http://media.neliti.com

Sudinkesjakbar. (2014) Evaluasi implementasi ANC terpadu dengan HIV dan sifilis. 2014 [diunduh 23 Oktober 2020]. Tersedia dari: http://www. Sudinkesjakbar.net

Widiastuti T, Kartasurya MI, Dharminto. (2014) Manajemen deteksi dini ibu hamil risiko tinggi pada pelayanan antenatal di tingkat Puskesmas Kabupaten Jepara. Jurnal Manajemen Kesehatan Indonesia. 2014;2(3):261-7. 